\title{
Glucagon-induced Hypocalcemia in the Rat: Effects of Maturation and Insulin
}

\author{
HAIM ELRAD, W. H. BERGSTROM ${ }^{(12)}$, AND TURKAN DAGOGLU \\ Perinatal Center and the Departments of Pediatrics and Obstetrics-Gynecology, State University of New York. Upstate \\ Medical Center, Syracuse, New York, USA
}

\section{Summary}

In adults of several species including man, a small transient decrease in serum calcium concentration follows glucagon administration in doses of 1 to $10 \mathrm{mg} / \mathrm{kg}$. The effects of maturation and insulin on this phenomenon were assessed by comparing the response of newborn and adult rats to equivalent doses of glucagon with and without prior insulin administration. After injection of 1 $\mu \mathrm{g} / \mathrm{g}$ of glucagon, the decrease in serum calcium concentration at $60 \mathrm{~min}$ was significant in the newborn rats $(-1.75 \mathrm{mg} / \mathrm{dl} ; P<$ $0.001)$ and not significant in the intact adults $(-0.07 \mathrm{mg} / \mathrm{dl} ; P>$ 0.1).

In pancreatomized adults, the decrease in serum calcium after the same dose of glucagon became significant $(-1.23 \mathrm{mg} / \mathrm{dl} ; P \leq$ 0.01 ). This hypocalcemic effect was prevented in the pancreatectomized adult rat if insulin in a dose of $0.01 \mu / g$ was given $15 \mathrm{~min}$ before glucagon. In the newborn rats, the same dose of insulin decreased the hypocalcemic effect, but the change was still significant $(-0.74 \mathrm{mg} / \mathrm{dl} ; P<0.01)$.

Glucagon decreased serum calcium at one hr in newborn rats but not in adults. After pancreatectomy, the adult response to glucagon was significant and similar to that of the newborn. Insulin cancelled this effect of glucagon in the pancreatectomized adults and reduced it in the newborns.

\section{Speculation}

Hypocalcemia in the neonatal period is a common and probably multifactorial disorder. Glucagon is known to be a hypocalcemic agent; this effect is decreased by insulin. Because insulin secretion is sluggish in the neonatal period, glucagon may have a clinically significant effect on serum calcium concentration at this time.

The frequency and severity of hypocalcemia within the first $\mathbf{4 8}$ hr of life are increased by prematurity, perinatal trauma, hypoxia, and maternal diabetes $(3,10)$. Functional hypoparathyroidism has been demonstrated in some of these situations $(3,10)$, but not all instances of hypocalcemia can be explained on this basis (3). Inasmuch as neonatal hypocalcemia is evidently a multifactorial disorder, all agents capable of affecting calcium homeostasis deserve consideration. Glucagon can lower serum calcium concentration in a variety of mammals including man $(2,6-9,11)$, but no studies of this phenomenon in the neonatal period have been reported. Grajwer et al. (5) have pointed out that a large increase in immunoreactive plasma glucagon occurs within the first two hr after delivery. Because the newborn infant is particularly susceptible to disturbances of calcium homeostasis, we designed the following experiments to test the effects of maturation on the response of serum calcium concentration to exogenous glucagon.

\section{MATERIALS AND METHODS}

Three groups of albino rats (strain TAC: SD/N f BR) were used: I. newborn (less than $48 \mathrm{hr}$ old), average wt, $7 \pm 0.1 \mathrm{~g}$. II. intact adults, average wt, $200 \pm 20 \mathrm{~g}$. III. pancreatectomized adults, average wt, $200 \pm 20 \mathrm{~g}$. Glucagon, given IP or IV as noted below, was diluted in normal saline (after adjusting the $\mathrm{pH}$ to 2.7) so that the total volume given was $0.01 \mathrm{ml} / \mathrm{g}$ of body weight. Crystalline insulin similarly diluted was given as noted $15 \mathrm{~min}$ before glucagon. Controls received equivalent volumes of normal saline. Blood samples were secured in group I by decapitation. In groups II and III, venous blood was drawn under chloral hydrate anesthesia; this agent was also used for pancreatectomy. Calcium was measured by the method of Bett and Fraser (I) as adapted for the Oxford titrator. Results are given as mean \pm S.E., and differences between group means were assigned significance by Student's $t$ test.

\section{RESULTS}

Figure 1 and Table 1 show the effects of glucagon in group $I$. At $60 \mathrm{~min}$, a significant decrease in calcium followed administration of $0.1 \mu \mathrm{g} / \mathrm{g}$. The effect of $1.0 \mu \mathrm{g} / \mathrm{g}$ was greater: no further change followed $10 \mu \mathrm{g} / \mathrm{g}$. Because the maximal effect appeared 60

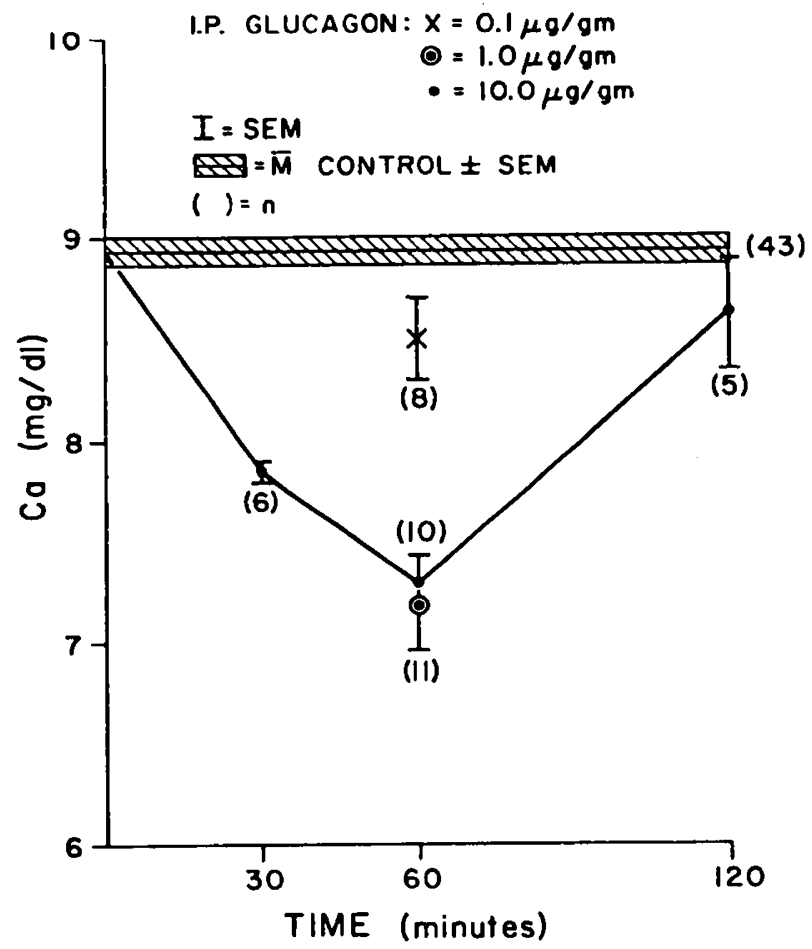

Fig. 1. Changes in serum calcium concentration after IP glucagon in newborn rats. The effects of three different doses are compared at $60 \mathrm{~min}$. The time course is shown for the highest dose studied $(10 \mu \mathrm{g} / \mathrm{g})$. 
Table 1. Effects of glucagon (G) and insulin (I) on serum calcium concentration

\begin{tabular}{|c|c|c|c|c|}
\hline Group & $n$ & Treatment & Calcium (mg/dl) & $\Delta \mathrm{CA}(\mathrm{mg} / \mathrm{dl}) P$ \\
\hline I (Newborn) & $\begin{array}{l}43 \\
11 \\
10 \\
19\end{array}$ & $\begin{array}{l}\text { Control } \\
\text { G, } 1.0 \mu \mathrm{g} / \mathrm{g} ; 60 \mathrm{~min} \\
\mathrm{I}, 0.01 \mathrm{U} / \mathrm{g} ; 75 \mathrm{~min} \\
\text { G + I }\end{array}$ & $\begin{array}{l}8.94 \pm 0.07^{1} \\
7.13 \pm 0.22 \\
9.44 \pm 0.09 \\
8.20 \pm 0.10\end{array}$ & $\begin{aligned}-1.8 \pm 0.22 & <0.01 \\
+0.50 \pm 0.09 & <0.01 \\
0.74 \pm 0.10 & <0.01\end{aligned}$ \\
\hline II (Intact adults) & $\begin{array}{l}23 \\
12 \\
10\end{array}$ & $\begin{array}{l}\text { Control } \\
\text { G, } 1.0 \mu \mathrm{g} / \mathrm{g} \text { IP; } 60 \mathrm{~min} \\
\mathrm{G}, 0.5 \mu \mathrm{g} / \mathrm{g} \text { IV; } 60 \mathrm{~min}\end{array}$ & $\begin{array}{l}8.75 \pm 0.08 \\
8.71 \pm 0.14 \\
8.94 \pm 0.18\end{array}$ & $\begin{array}{l}-0.14 \pm 0.14 \mathrm{NS}^{2} \\
+0.19 \pm 0.18 \mathrm{NS}\end{array}$ \\
\hline $\begin{array}{l}\text { III Pancreatectomized } \\
\text { adults }\end{array}$ & $\begin{array}{r}24 \\
10 \\
6\end{array}$ & $\begin{array}{l}\text { Control } \\
\mathrm{G}, 0.5 \mu \mathrm{g} / \mathrm{g} \text { IV; } 60 \mathrm{~min} \\
\mathrm{G}+1\end{array}$ & $\begin{array}{l}7.99 \pm 0.09 \\
6.76 \pm 0.10 \\
7.85 \pm 0.11\end{array}$ & $\begin{array}{l}-1.23 \pm 0.10<0.01 \\
-0.14 \pm 0.11 \mathrm{NS}\end{array}$ \\
\hline
\end{tabular}

\footnotetext{
${ }^{1}$ Mean \pm S.E.

${ }^{2} \mathrm{NS}$, not significant.
}

min after $1 \mu \mathrm{g} / \mathrm{g}$, this dose and interval were used to compare responses in the three groups studied.

In Group II (intact adults), neither $1 \mu \mathrm{g} / \mathrm{g}$ IP nor $0.5 \mu \mathrm{g} / \mathrm{g}$ IV affected serum calcium at $60 \mathrm{~min}$ (Fig. 2; Table 1 ). After pancreatectomy (group III), a glucagon dose of $0.5 \mu \mathrm{g} / \mathrm{g}$ IV led to a decrease of $1.23 \mathrm{mg} / \mathrm{dl}$ at $60 \mathrm{~min}$ (Fig. 2; Table 1).

In group I, administration of insulin $15 \mathrm{~min}$ before glucagon reduced the degree of hypocalcemia at $60 \mathrm{~min}$ from $-1.81 \pm 0.22$ to $-0.74 \pm .10 \mathrm{mg} / \mathrm{dl}(P<0.01)$. Pancreatectomized adults (group III) showed no change in calcium when glucagon was preceded by insulin.

\section{DISCUSSION}

The demonstration that newborn rats are more susceptible than adults to the hypocalcemic effect of glucagon is not surprising in view of the precarious state of calcium homeostasis in the neonatal period. In this case, pancreatic rather than parathyroid function appears to be a major factor. Insulin increased calcium concentration in the newborn rats. Pancreatectomized adults with intact parathyroids showed postglucagon hypocalcemia, and exogenous insulin mitigated hypocalcemia in newborns and abolished it in adults. This finding contrasts with results reported by Williams $e t$ al. (11) who found no interaction between 25 munits of insulin and $200 \mu \mathrm{g}$ of glucagon. At these doses, the molar ratio was 0.0029 (MW of glucagon, 3485); we used 10 munits of insulin per $1.0 \mu \mathrm{g}$ of glucagon, giving an insulin/glucagon molar ratio of 0.23 (IU insulin $=40 \mu \mathrm{g} ; \mathrm{MW}=6000$ ). Previous studies have shown that the hypocalcemic effect of glucagon was not dependent on the presence of the thyroid, parathyroid, or kidneys $(6,8,11)$. Hyperglycemia induced by glucose infusion did not affect serum calcium concentration (11). In vitro, bone calcium release in response to parathyroid hormone or to cyclic adenosine $3^{\prime}: 5^{\prime}$-monophosphate was inhibited by glucagon as it was by calcitonin and cortisol (4, 9). These findings suggest that glucagon affects the equilibrium between bone mineral and interstitial fluid by a mechanism presently obscure. Whether this action, alone or in conjunction with other factors, is clinically important cannot be assessed on the basis of currently available data. Inhibition by insulin suggests that the mechanism may be related to bone cell carbohydrate metabolism.

\section{REFERENCES AND NOTES}

I. Bett. J. M.. and Fraser. G. P.: A rapid micro method for determining serum calcium. Clin. Chim. Acta, 4: 346 (1959).

2. Birge. S. J., and Avioli, L. V.: Glucagon-induced hypocalcemia in man. J. Clin. Endocrinol., 29: 213 (1969).

3. David, L., and Anast, C. S.: Calcium metabolism in newborn infants. J. Clin. Invest., 54: 287 (1974).

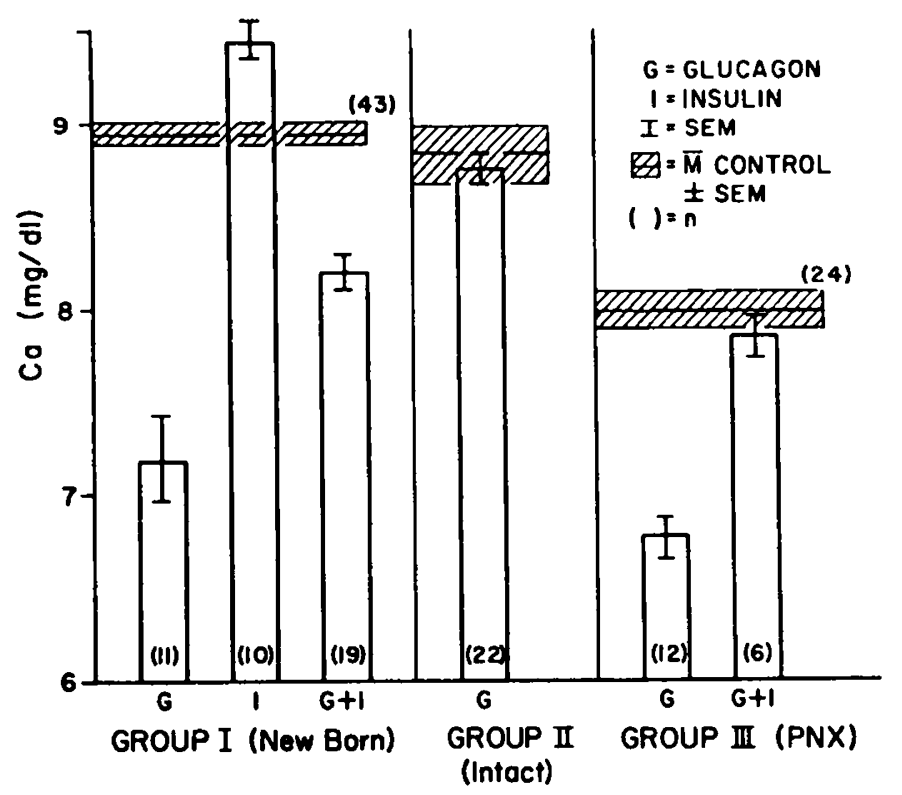

Fig. 2. Effects of glucagon and insulin alone and in combination. Group I = newborn $(7 \mathrm{~g})$. Groups II and III = adult $(200 \mathrm{~g})$. Insulin was given $75 \mathrm{~min}$ before sacrifice, and glucagon was given $60 \mathrm{~min}$ before sacrifice.

4. Gozariu, L., Minne, M., and Ziegler, R.: Rat Bone osteolysis in vitro: inhibitory effects of glucagon and cortisol. Horm. Metab. Res., 3: 225 (1971).

5. Grajwer, L. A., Sperling, M. A., Sack, J., and Fisher, D. A.: Possible mechanisms and significance of the neonatal surge in glucagon secretion: studies in newborn lambs. Pediatr. Res., 11: 833 (1977).

6. Hattner, R. S., Bernstein, D. S., Aliapoulios, M. A., George, B., and Rose, E.: The hypocalcemic effect of glucagon: demonstration of independence from endogenous calcitonin secretion in the rat. Acta Endocrinol., 64: 726 (1970).

7. Paloyon, E., Paloyon, D., and Harper, P. V.: Glucagon-induced hypocalcemia. Metabolism, 16: 35 (1967).

8. Scandellari. C.. Conte. N.. Federsfil. G.. Frezzolo. S.. and Trijotto. A.: A propos du mechanisme de l'effet hypocalcemiant du glucagon chez l'homme. Ann. Endocrinol., 33: 464 (1972).

9. Stern. P. M., and Bell. N. H.: Effects of glucagon on serum calcium in the rat and on bone resorption in tissue culture. Endocrinology, 87: 111 (1970).

10. Tsang. R. C., Light. I. J.. Sutherland. J. M.. and Kleinman. L. I.: Possible pathogenetic factors in neonatal hypocalcemia of prematurity. J. Pediatr., 82 . 423 (1973).

11. Williams. G. A.. Bowser. E. N., and Henderson. W. J.: Mode of hypocalcemic action of glucagon in the rat. Endocrinology. 85: 537 (1969).

12. Requests for reprints should be addressed to: W. H. Bergstrom, M.D., Dept. of Pediatrics, Upstate Medical Center, 750 E. Adams St., Syracuse, N. Y. 13210 (USA).

13. Received for publication August 14, 1978.

14. Accepted for publication August 13. 1979. 